\title{
Dietary Intake of Sodium during Infancy and the Cardiovascular Consequences Later in Life: A Scoping Review
}

\author{
Nikki E. Emmerik ${ }^{a} \quad$ Femke de Jong $^{b}$ Ruurd M. van Elburg ${ }^{c}$ \\ a Ministry of Health, Welfare and Sport, The Hague, The Netherlands; ${ }^{b}$ Department of General Practice, Amsterdam \\ University Medical Centers, Amsterdam, The Netherlands; ' ${ }^{C}$ Emma Children's Hospital, Amsterdam University \\ Medical Centers, Amsterdam, The Netherlands
}

\section{Keywords}

Sodium intake $\cdot$ Health outcomes · Infant nutrition ·

Cardiovascular risk factors · Blood pressure

\section{Abstract}

Background: High sodium intake is a leading cause of cardiovascular diseases in adults. Further, there is evidence that events in early life are predictors for health outcomes in later life. However, little is known about the impact of early sodium intake on (cardiovascular) health outcomes in later life. Summary: We performed a scoping review of 25 articles, including 11 review studies, 8 randomized controlled trials, 5 prospective cohort studies, and 1 retrospective cohort study, all describing the relationship between the amount of sodium intake during the first 6 months after birth and the health effects and/or risk to cardiovascular disease later in life. We divided the results into 2 different groups: human and animal studies. Key Messages: The results show that high sodium intake in the first 6 months after birth may lead to negative health effects such as higher blood pressure, due to factors like salty taste preference and alterations of the renal karger@karger.com Karger" www.karger.com/anm

\section{(C) 2020 The Author(s)}

Published by S. Karger AG, Base

Karger

Open access

This article is licensed under the Creative Commons AttributionNonCommercial-NoDerivatives 4.0 International License (CC BYNC-ND) (http://www.karger.com/Services/OpenAccessLicense). Usage and distribution for commercial purposes as well as any distribution of modified material requires written permission. system. The findings of this study suggest that the amount of sodium in the diet of an infant in the first 6 months after birth may have an impact on cardiovascular health outcomes in later life.

(C) 2020 The Author(s)

Published by S. Karger AG, Basel

\section{Introduction}

The relation between events in early life and health conditions in later life has been extensively studied, indicating that environmental factors in early life have thorough effects on vulnerability on disease later in life [1]. One of its leading principles is the Developmental Origins of Health and Disease-Hypothesis, often referred to as "The Barker Hypothesis" [2]. The Barker Hypothesis proposes that early developmental adverse influences, for example, poor fetal and postnatal nutrition, are implicat-

N.E.E. and F.J. contributed equally to this work. 
ed to adaptations that program future propensity to permanent negative health outcomes in physiology and metabolism, such as cardiovascular diseases, obesity, and diabetes [3].

In recent years, the consumption of sodium in adults has been thoroughly investigated and there has been convincing body of evidence from epidemiological, clinical, and experimental studies demonstrating that high sodium intake in adulthood has profound negative health effects, especially cardiovascular diseases, such as high blood pressure (BP) and stroke [4-6]. The mechanistic pathways by which sodium leads to arterial alterations and increase of BP are thought to mature from conception until adulthood and are primarily studied in animals models [7]. In humans, sodium intake after birth was evaluated in several studies, which conclude that the majority of infants ingest excessive amounts of sodium in early life [8-11]. According to these studies, sodium consumption in infants is often higher than recommended values by different national and international guidelines, resulting in approximately $4-8$ times higher sodium consumption [8-11].

Altogether, high sodium intake may have a negative influence on health in later life, and the consequences of high sodium intake in early infancy are not well understood. The aim of this study was to perform a scoping review of the literature on the association between sodium intake in the first 6 months after birth and cardiovascular health outcomes later in life.

\section{Methods}

Search Strategy

We searched the literature regarding sodium intake in the first 6 months after birth. We included all original articles as well as review articles based on either human or animal studies, published between January 1980 and April 2019. As the mechanistic pathways of high sodium intake are mainly studied in animal studies, we decided to include both human and animal studies. In addition, articles published before 1980 were excluded because lead was used in drinking water pipes before this date, affecting the levels of minerals in drinking water, which may influence the outcomes. We explicitly searched for articles focusing on the relation between sodium intake in infancy and cardiovascular health outcome in later life. For our search, we defined in later life as in adolescence or adulthood. The following databases were used to obtain the literature: Medline, Embase, and $\mathrm{CAB}$ Abstract and the following search strings were used: "(sodium intake OR salt intake OR sodium consumption OR salt consumption OR $\mathrm{NaCl}$ intake OR $\mathrm{NaCl}$ consumption NOT parenteral) AND (diabetes OR noncommunicable disease OR cardiovascular disease* OR renal or kidney OR metabolic syndrome* OR insulin OR lifespan OR hypertension OR coronary heart disease) AND (baby OR babies OR

Dietary Sodium Intake during Infancy

and Later Cardiovascular Consequences infant* OR newborn* OR neonate* OR pediatric* OR paediatric* OR toddler*).”

\section{Selection of Articles}

The literature search in the databases was conducted by a clinical librarian on April 25, 2019 and contained 2,475 records after duplicates were removed. To ensure that all relevant articles were included, we hand-searched bibliographies of all included articles and used the "similar articles" function in PubMed. We identified 4 more records by hand searching. Two authors (N.E.E. and F.J.) independently reviewed all records and 2,364 articles were excluded based on reviewing the title and abstract (Fig. 1). Of the remaining 115 articles, 25 articles met the inclusion criteria for our scoping review. There were 2 duplicated cohorts, both in 2 articles. We included all 4 articles because the articles respectively described 2 different outcomes in one cohort $[12,13]$ and 2 similar outcomes at different time points $[14,15]$. Finally, 25 articles were included in the scoping review. Any differences were resolved by reaching agreement through discussion. If agreement was not achieved, differences in opinion were solved through discussion with a third author (R.M.E.). There was one article written in French; a native speaker translated this article.

\section{Data Extraction}

The different articles were divided into 2 categories: human and animal studies. The first category was then subdivided into fullterm born and preterm born infants and/or low birth weight infants because preterm birth and/or low birth weight is a confounder for cardiovascular health outcome (40). We extracted the following information of each study: (1) author and year of publication; (2) country of publication and/or investigation; (3) study aim; and (4) study outcome. In addition, of the human studies, we extracted the study design, sample size and method of sodium intake assessment, whereas of the animal studies we extracted the study design, animal species, sample size, and method of $\mathrm{Na}$ intake assessment. Two studies $[16,17]$ described results of children age 4 months to 8 years. In this case, we only used the results until the age of 6 months.

\section{Results}

\section{Study Characteristics}

We identified 25 studies: 18 human studies and 7 animal studies. Furthermore, 11 were review studies, 8 were randomized controlled trials, 5 prospective cohort studies, and 1 retrospective cohort study (Tables 1-4).

\section{Human Studies}

Term Born Infants

At birth, infants show an aversion or indifference to salty solutions in contrast to plain water [18-21]. According to Liem [21], the preference for salty taste develops because of repeated exposure to salty foods [21].

A relation was found between early salt intake and salt acceptance and/or preference in adulthood [17-19, 22, 23]. For example, Stein et al. [19] found that infants on an 
Fig. 1. Selection of articles included in the scoping review.

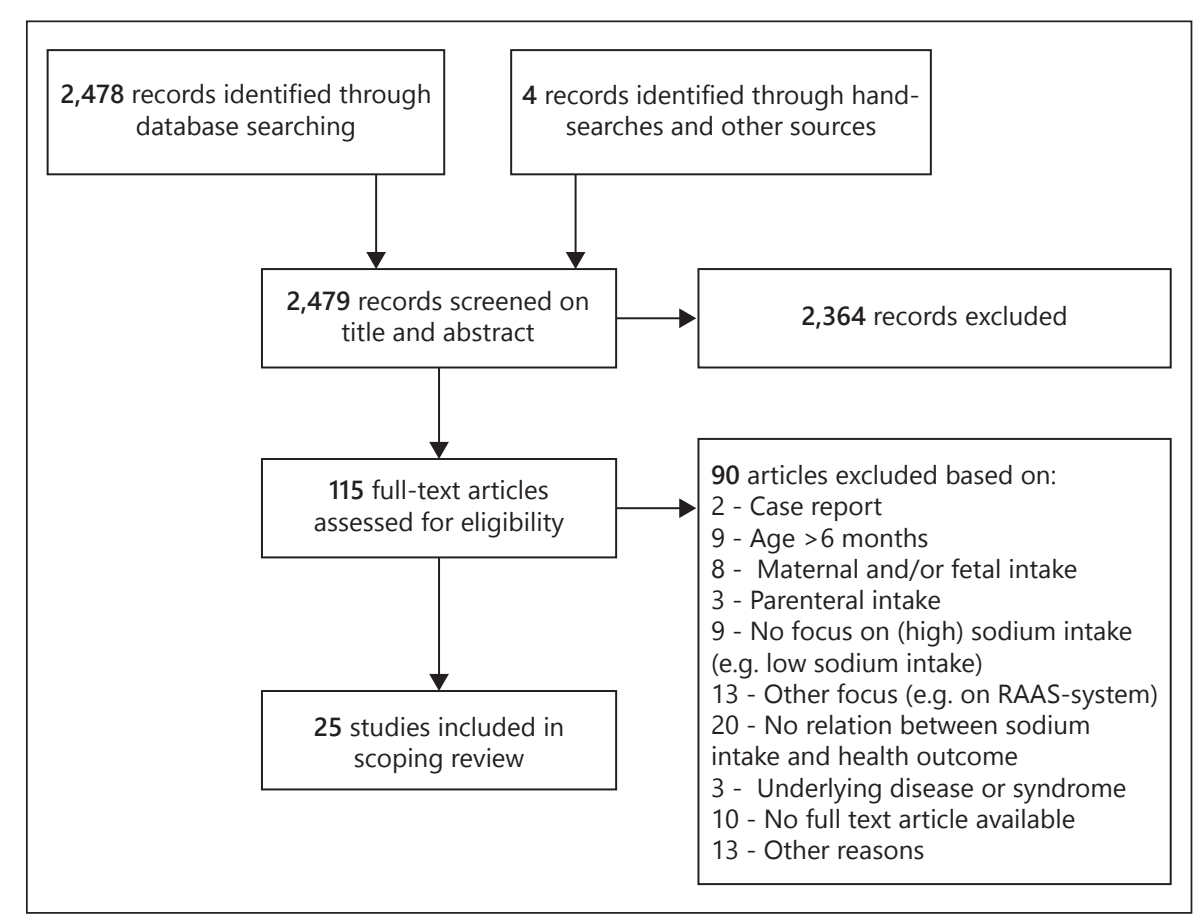

early high sodium diet $(7.82 \mathrm{~g} / \mathrm{L} \mathrm{NaCl})$ at 2 months were more likely to accept salt at 6 months than the low sodium group (3.91 g/L NaCl). Similarly, Schwartz et al. [17] found that the development of salt acceptance and preference starts between 3 and 6 months, and can predict salt intake of adults. The most sensitive period for infants' salt acceptance and preference is between 2 and 6 months of age [22, 23]. In addition, Lava et al. [24] described that reduced salt intake benefits children and further they described specific risk groups with an even higher prevalence of salt sensitivity and therefore an increased risk of developing high $\mathrm{BP}$, including overweight, preterm, and/or small for gestational age and African American children.

Besides taste imprinting, early dietary sodium intake seems to affect later BP. To determine the effect of sodium intake on BP, infants were randomized either to a low $(0.05-0.32 \mathrm{~g} / \mathrm{L})$ or a normal $(0.52-1.76 \mathrm{~g} / \mathrm{L})$ sodium diet during the first 6 months of life [25]. Systolic BP was significant lower in the low-sodium group (114.1 $\mathrm{mm} \mathrm{Hg}$ ) compared to the normal-sodium group $(116.1 \mathrm{Hg})$ and total sodium intake over 6 months was 3 times lower in the low-sodium group [25]. At the 15-year follow-up, Geleijnse et al. [15] found that the low-sodium group had lower systolic and diastolic BP (3.6 and $2.2 \mathrm{~mm} \mathrm{Hg}$ respectively) than in the normal-sodium group. Interestingly, differences in BP between low- and normal-sodium groups were significantly larger than any reported effects of low-salt diets in adults. This suggests that sodium in infancy plays a more important role than salt reduction in adults, as well as that sodium intake during infancy may be a key factor for later BP $[26,27]$. As $44 \%$ of sodium consumption in infants has been reported to be via tap water, BP in infants receiving milk formula prepared with low-sodium mineral water $(32 \mathrm{mg} / \mathrm{L})$ or high-sodium tap water $(196 \mathrm{mg} / \mathrm{L})$ or breast milk was evaluated [28]. Milk formula prepared with high-sodium tap water results in saltier milk $(382 \mathrm{mg} / \mathrm{L})$ compared to low-sodium mineral water $(218 \mathrm{mg} / \mathrm{L})$ or breast milk (161 mg/L) [28]. After adjustment for age, sex and energy intake and sodium intake at 4 months was positively associated with systolic $\mathrm{BP}$ at 7 years $(p=0.02)$ [29]. One study found no significant effect of dietary sodium on BP [16]. Geleijnse and Grobbee [14] suggested that high levels of sodium may cause early kidney damage. More specific, as high levels of sodium intake during early kidney development may cause abnormal sodium handling and increased salt sensitivity, BP elevations may occur. According to the study, the kallikrein system plays an important role in the early kidney development and its maturation is affected by sodium intake [14]. Three mechanisms for the relation between sodium intake and BP have been proposed: (1) high sodium intake result in an expansion of extracellular fluid volume. (2) Sodium has a direct influence on peripheral vascular resistance [25] and (3) salt taste re- 
Table 1. Human original studies

\begin{tabular}{|c|c|c|c|c|c|}
\hline $\begin{array}{l}\text { Authors, year of } \\
\text { publication; Country }\end{array}$ & $\begin{array}{l}\text { Study } \\
\text { design }\end{array}$ & $\begin{array}{l}\text { Sample } \\
\text { size* }^{*}\end{array}$ & $\begin{array}{l}\text { Method of sodium } \\
\text { intake assessment }\end{array}$ & Study aim & Study outcome \\
\hline $\begin{array}{l}\text { Stein et al. [19], } \\
\text { 2012; USA }\end{array}$ & PCS & 61 & $\begin{array}{l}\text { Taste: intake test to } 0.17 \text { and } 0.34 \mathrm{~mol} \\
\mathrm{NaCl} / \mathrm{L} \text { in water at } 2 \text { and } 6 \text { months } \\
\text { old; questionnaire by mother }\end{array}$ & $\begin{array}{l}\text { Investigate whether dietary experience } \\
\text { with foods containing sodium is } \\
\text { associated with development of } \\
\text { infant salty taste preference }\end{array}$ & $\begin{array}{l}\text { There is an influential role of } \\
\text { early dietary experience in } \\
\text { shaping salty taste responses in } \\
\text { infants and young children }\end{array}$ \\
\hline $\begin{array}{l}\text { Schwartz et al. [17], } \\
\text { 2009; France }\end{array}$ & PCS & 90 & Taste: acceptance of water/tastant & $\begin{array}{l}\text { Evaluate the acceptance of tastes and } \\
\text { their developmental changes over } \\
\text { the first year }\end{array}$ & $\begin{array}{l}\text { It is important to understand } \\
\text { the role of taste preferences on } \\
\text { food acceptance in this } \\
\text { population in a context of } \\
\text { increasing childhood obesity }\end{array}$ \\
\hline $\begin{array}{l}\text { Brion et al. [29], } \\
\text { 2008; UK }\end{array}$ & PCS & 533 & $\begin{array}{l}\text { 1-day intake diaries completed by } \\
\text { the main carer; evaluated with } \\
\text { weight and food codes }\end{array}$ & $\begin{array}{l}\text { Prospectively assess associations } \\
\text { between sodium intake in infancy } \\
\text { and BP at } 7 \text { years }\end{array}$ & $\begin{array}{l}\text { The association between } \\
\text { sodium intake at } 4 \text { months and } \\
\text { future systolic BP requires } \\
\text { replication in studies }\end{array}$ \\
\hline $\begin{array}{l}\text { Pomeranz et al. } \\
{[28], 2002 ; \text { Israel }}\end{array}$ & PCS & 58 & $\begin{array}{l}\text { Different sodium concentrations of } \\
\text { milk formulae and breast milk and } \\
\text { measurement of urinary sodium } \\
\text { (creatinine ratio) }\end{array}$ & $\begin{array}{l}\text { Evaluate changes in BP during the } \\
\text { first } 2 \text { months of life in neonates } \\
\text { receiving low-sodium mineral water, } \\
\text { high-sodium tap water, or breast milk }\end{array}$ & $\begin{array}{l}\text { BP in the neonates is increased } \\
\text { by a high-sodium intake via } \\
\text { drinking water }\end{array}$ \\
\hline $\begin{array}{l}\text { Zinner et al. [30], } \\
\text { 2002; USA }\end{array}$ & RCT & 283 & $\begin{array}{l}\text { Response to } 3 \text { different solutions of } \\
\text { sodium and water }\end{array}$ & $\begin{array}{l}\text { Test the association between neonatal } \\
\mathrm{BP} \text { and salt response }\end{array}$ & $\begin{array}{l}\text { Neonates can distinguish } \\
\text { between dilute salt solutions and } \\
\text { water. This response is related to } \\
\text { BP and might be a potential risk } \\
\text { for high BP later in life }\end{array}$ \\
\hline $\begin{array}{l}\text { Geleijnse et al. } \\
\text { [15], 1997; } \\
\text { The Netherlands }{ }^{1}\end{array}$ & RCS & 167 & Sodium intake, 24 -h urinary excretion & $\begin{array}{l}\text { Investigate whether contrasting levels of } \\
\text { sodium intake in infancy are associated } \\
\text { with BP differences later in life }\end{array}$ & $\begin{array}{l}\text { Sodium intake in infancy may } \\
\text { be important in relation to BP } \\
\text { later in life }\end{array}$ \\
\hline $\begin{array}{l}\text { Lucas et al. [31], } \\
\text { 1988; UK }\end{array}$ & $\mathrm{RCT}$ & 347 & Different amounts of sodium intake & $\begin{array}{l}\text { Investigate whether the level of salt } \\
\text { intake in early life of preterm born } \\
\text { infants influences later BP }\end{array}$ & $\begin{array}{l}\text { No significant effect of early diet } \\
\text { on BP at } 18 \text { months was found }\end{array}$ \\
\hline $\begin{array}{l}\text { Hofman et al. } \\
\text { [25], 1983; } \\
\text { The Netherlands }\end{array}$ & RCT & 476 & $\begin{array}{l}\text { Measurement of sodium intake and } \\
\text { urine excretion }\end{array}$ & $\begin{array}{l}\text { Study the effect of sodium intake on the } \\
\text { level and evolution of BP in healthy } \\
\text { new-born infants }\end{array}$ & $\begin{array}{l}\text { Sodium intake is causally related } \\
\text { to the level of BP }\end{array}$ \\
\hline $\begin{array}{l}\text { Whitten and } \\
\text { Stewart [16], } \\
\text { 1980; Sweden }\end{array}$ & PCS & 27 & $\begin{array}{l}\text { Calculation of amount of sodium in } \\
\text { infant food }\end{array}$ & $\begin{array}{l}\text { Determine the effects in infants of a } \\
\text { low vs. high level of salt intake on BP } \\
\text { and several related metabolic parameters }\end{array}$ & $\begin{array}{l}\text { There was no indication that } \\
\text { the salted foods imprinted a } \\
\text { preference for salt at } 8 \text { years }\end{array}$ \\
\hline
\end{tabular}

${ }^{1}$ Same cohort, but different time points.

* Only infants included for this review are taken into account in the table.

RCT, randomized controlled trial; PCS, prospective cohort study; RCS, retrospective cohort study; BP, blood pressure.

sponses relate to BP regulation and therefore becomes a risk factor for later high BP [30].

\section{Preterm Born Infants}

Only one study reported on sodium intake and later health outcomes in preterm born infants but follow-up was only performed up to 18 months [31]. Lucas et al. [31] randomized preterm born infants to diets with different amounts of sodium in infancy and measured BP at the age of 18 months. The results did not show a difference in BP between the 2 groups.

Dietary Sodium Intake during Infancy and Later Cardiovascular Consequences

\section{Animal Studies}

All animal studies included for this review were performed in rats. We found that high sodium intake in the first week of life was associated with adverse health outcomes in later life in several animal experiments $[12,13$, 32-36], whereas high sodium intake after this period was not, suggesting that the timing of taste exposure is important. In line with this, the results of Moreira et al. [33] indicate that an overload of sodium intake during the postnatal period permanently alters the excretion patterns and spontaneous sodium intake patterns in adult- 
Table 2. Human review studies

\begin{tabular}{|c|c|c|}
\hline $\begin{array}{l}\text { Authors, year of } \\
\text { publication; Country }\end{array}$ & Study aim & Study outcome \\
\hline $\begin{array}{l}\text { Liem [21], } \\
\text { 2017; Australia }\end{array}$ & $\begin{array}{l}\text { Provide an overview of the current knowledge about the development } \\
\text { of salt taste perception and salt taste liking during infancy and childhood } \\
\text { and its relationship to food consumption and health outcomes }\end{array}$ & $\begin{array}{l}\text { Decreasing exposure to salty tasting foods during early } \\
\text { infancy is recommended, as salt plays an important role } \\
\text { in children's liking for a variety of foods }\end{array}$ \\
\hline $\begin{array}{l}\text { Lava et al. [24], } \\
\text { 2015; Switzerland }\end{array}$ & $\begin{array}{l}\text { Consider and highlight some key papers focusing on the role of salt on } \\
\text { BP in childhood }\end{array}$ & $\begin{array}{l}\text { A sodium-poor diet seems to have the same } \\
\text { cardiovascular protective effects as among adults }\end{array}$ \\
\hline $\begin{array}{l}\text { Mennella [23], } \\
\text { 2014; USA }\end{array}$ & $\begin{array}{l}\text { Highlight the science that shows that children naturally prefer } \\
\text { higher levels of sweet and salty tastes and reject lower levels of } \\
\text { bitter tastes than do adults }\end{array}$ & $\begin{array}{l}\text { It is possible to shape and modify flavor and food } \\
\text { preferences more toward healthy food and less toward } \\
\text { salty and sweet tastes }\end{array}$ \\
\hline $\begin{array}{l}\text { Hanevold [18], } \\
\text { 2013; USA }\end{array}$ & $\begin{array}{l}\text { Focus on the link between BP and sodium intake and the impact } \\
\text { of sodium on cardiovascular health and morbidity }\end{array}$ & $\begin{array}{l}\text { It is recommended to avoid high-sodium diets in early } \\
\text { childhood to contribute to a healthy lifestyle }\end{array}$ \\
\hline $\begin{array}{l}\text { Strazzullo et al. } \\
{[20], 2012 \text {; Italy }}\end{array}$ & $\begin{array}{l}\text { Review whether salt intake during childhood, largely exceeding } \\
\text { the physiological needs, has an impact on the risk to develop } \\
\text { hypertension and cardiovascular disorders later in life }\end{array}$ & $\begin{array}{l}\text { Children should not get habitual to the levels of } \\
\text { salt intake, which are common in adults and are well } \\
\text { known to be harmful }\end{array}$ \\
\hline $\begin{array}{l}\text { Beauchamp and } \\
\text { Mennella [22], } \\
\text { 2011; USA }\end{array}$ & $\begin{array}{l}\text { Outline several of the important factors that shape flavor } \\
\text { preferences in humans }\end{array}$ & $\begin{array}{l}\text { Early experiences shape long-term food and flavor } \\
\text { preferences that can impact upon later health }\end{array}$ \\
\hline $\begin{array}{l}\text { Wu and Chen } \\
\text { [27], 2009; Taiwan }\end{array}$ & $\begin{array}{l}\text { Sort out and summarize the short- and long-term health } \\
\text { effects of breastfeeding and the timing and composition of } \\
\text { complementary foods }\end{array}$ & $\begin{array}{l}\text { Dietary components in infancy, including sodium were } \\
\text { found to have an influence on future metabolic profiles }\end{array}$ \\
\hline $\begin{array}{l}\text { Lawlor and Smith } \\
{[26], 2005 \text {; UK }}\end{array}$ & $\begin{array}{l}\text { Provide a summary of the current evidence concerning the } \\
\text { early life determinants of adult BP }\end{array}$ & $\begin{array}{l}\text { There is evidence that early life factors are important } \\
\text { determinants of adult BP }\end{array}$ \\
\hline $\begin{array}{l}\text { Geleijnse and } \\
\text { Grobbee [14], 2002; } \\
\text { The Netherlands }\end{array}$ & $\begin{array}{l}\text { Review the current evidence on the relationship between } \\
\text { sodium and BP in early life, and how this may influence the } \\
\text { risk of hypertension }\end{array}$ & $\begin{array}{l}\text { It remains unclear whether high sodium intake in infants } \\
\text { and children increases their risk of hypertension later in } \\
\text { life }\end{array}$ \\
\hline
\end{tabular}

BP, blood pressure.

hood. Furthermore, sodium intake during postnatal period promotes salty food preferences in adulthood [33]. In addition, BP increases due to salt supplementation during suckling and BP of high-salt-diet offspring is higher [35]. Postnatal salt intake suppresses the postnatal rise in renal kallikrein gene expression, confirming that sodium intake is important during the maturation of renal kallikrein synthesis [32]. Additionally, angiotensin II receptors may be up regulated due to high dietary salt [13].

\section{Discussion}

Our scoping review suggests that high sodium intake in infancy may have adverse outcomes on cardiovascular health in later life [25]. Infants seem to be less capable to excrete high levels of sodium and there appears to be a direct association between dietary sodium intake and hypertension later in life $[37,38]$.
We decided to review both the direct as well as indirect consequences of salt intake in early life on cardiovascular health later in life. With the increasing survival of this specific target group, more preterm born infants reach adulthood. There is an association between preterm birth and later systolic BP (mean follow-up range 6-30 years) [39]; therefore, it would be important to determine the association between early sodium intake levels and cardiovascular outcome in adolescence and adulthood.

This may indicate that the effect of sodium intake in early life has different outcomes in preterm born infants' later life. Unfortunately, only one study focused on preterm born infants [31]. The authors found no negative effect of early high sodium intake in the preterm born infants on BP later in life. However, the follow-up period was only 18 months and the relationship between high sodium intake in preterm-infancy and cardiovascular diseases later in life was not examined in this study. Furthermore, Singhal et al. [40] stated that in preterm born 
Table 3. Animal original studies

\begin{tabular}{|c|c|c|c|c|c|c|}
\hline $\begin{array}{l}\text { Authors, year of } \\
\text { publication; Country }\end{array}$ & $\begin{array}{l}\text { Study } \\
\text { design }\end{array}$ & $\begin{array}{l}\text { Animal } \\
\text { specie }\end{array}$ & $\begin{array}{l}\text { Sample } \\
\text { size }\end{array}$ & $\begin{array}{l}\text { Method of } \mathrm{Na} \\
\text { intake assessment }\end{array}$ & Study aim & Study outcome \\
\hline $\begin{array}{l}\text { Moreira et al. [33], } \\
\text { 2014; Brazil }\end{array}$ & RCT & Rats & 23 & $\begin{array}{l}\text { Amount of } \mathrm{Na} \text { intake, plasma } \\
\mathrm{Na} \text { concentration, urinary } \mathrm{Na} \\
\text { concentration, } \mathrm{Na} \text { excretion rate }\end{array}$ & $\begin{array}{l}\text { Evaluate the effects of increased } \\
\mathrm{Na} \text { overload during childhood on } \\
\text { induced water and } \mathrm{Na} \text { intakes and } \\
\text { on cardiovascular parameters in } \\
\text { adulthood }\end{array}$ & $\begin{array}{l}\text { Postnatal sodium overload alters } \\
\text { behavioural and cardiovascular } \\
\text { regulation in adulthood, as it } \\
\text { induces an increase in arterial BP }\end{array}$ \\
\hline $\begin{array}{l}\text { Curtis et al. [12], } \\
\text { 2004; } \text { USA }^{1}\end{array}$ & RCT & Rats & 22 & $\begin{array}{l}\text { Amount of } \mathrm{Na} \text { intake, plasma } \\
\mathrm{Na} \text { concentration and urinary } \\
\mathrm{Na} \text { concentration }\end{array}$ & $\begin{array}{l}\text { Evaluate the effect of early } \\
\text { dietary } \mathrm{NaCl} \text { manipulations } \\
\text { on the relationship between } \\
\text { food and water intake during } \\
\text { on demand feeding in weaning } \\
\text { and adult rats }\end{array}$ & $\begin{array}{l}\text { Persistent changes in } \mathrm{NaCl} \text { intake } \\
\text { and in water intake associated } \\
\text { with } \mathrm{NaCl} \text { ingestion reflect } \\
\text { short-term behavioural effects }\end{array}$ \\
\hline $\begin{array}{l}\text { Smriga et al. [34], } \\
\text { 2002; Japan }\end{array}$ & $\mathrm{RCT}$ & Rats & 90 & $\begin{array}{l}\text { Na solution intake, } 24-\mathrm{h} \\
\text { urine excretion }\end{array}$ & $\begin{array}{l}\text { To investigate the effect of early oral } \\
\text { exposure to salt and sweet solutions } \\
\text { and the salt and sweet preferences in } \\
\text { adulthood }\end{array}$ & $\begin{array}{l}\text { A brief oral exposure to } \mathrm{NaCl} \\
\text { during a specific short period } \\
\text { of postnatal development } \\
\text { specifically increased } \\
\text { acceptance of high } \\
\text { concentrations of salty } \\
\text { and sweet solutions. }\end{array}$ \\
\hline $\begin{array}{l}\text { Contreras et al. } \\
{[13], 2000 ; \text { USA }^{1}}\end{array}$ & $\mathrm{RCT}$ & Rats & 22 & $\begin{array}{l}\text { Different amounts of } \\
\text { sodium in intake }\end{array}$ & $\begin{array}{l}\text { Investigate the long-term influence } \\
\text { of early dietary } \mathrm{NaCl} \text { on adult mean } \\
\text { arterial pressure and heart rate }\end{array}$ & $\begin{array}{l}\text { Exposure to high levels of } \\
\text { dietary } \mathrm{NaCl} \text { early in } \\
\text { development led to a persistent } \\
\text { increase in mean arterial } \\
\text { pressure in adulthood }\end{array}$ \\
\hline $\begin{array}{l}\text { El-Dahr et al. [32], } \\
\text { 1996; USA }\end{array}$ & $\mathrm{RCT}$ & Rats & 47 & $\begin{array}{l}\text { Amount of sodium intake, } \\
\text { renal activity, urine excretion }\end{array}$ & $\begin{array}{l}\text { Test the hypothesis that salt intake } \\
\text { regulates the ontogeny of renal } \\
\text { kallikrein gene expression and } \\
\text { enzymatic activity and urinary } \\
\text { kallikrein excretion }\end{array}$ & $\begin{array}{l}\text { Chronic salt loading suppresses } \\
\text { the postnatal rise in renal } \\
\text { kallikrein gene expression and } \\
\text { enzymatic activity }\end{array}$ \\
\hline
\end{tabular}

${ }^{1}$ Same cohort, but different outcome.

RCT, randomized controlled trial; BP, blood pressure.

Table 4. Animal review studies

\begin{tabular}{llll}
\hline $\begin{array}{l}\text { Authors, year of } \\
\text { publication; Country }\end{array}$ & $\begin{array}{l}\text { Animal } \\
\text { specie }\end{array}$ & Study aim & Study outcome \\
\hline Tekol [35], 2008; Turkey & Rats & $\begin{array}{l}\text { Review the significance of salt exposure during } \\
\text { the early life on the development of essential } \\
\text { hypertension }\end{array}$ & $\begin{array}{l}\text { Maternal and infantile dietary salt exposure may } \\
\text { cause hypertension later in life }\end{array}$ \\
\hline Holliday [36], 1995; USA & Rats & $\begin{array}{l}\text { Review experimental and clinical evidence of } \\
\text { whether primary hypertension later in life is } \\
\text { influenced by events in early life }\end{array}$ & BP in later life is affected by events early in life \\
\hline
\end{tabular}

BP, blood pressure.

infants, other factors besides high sodium intake in the first weeks of life, may lead to an increase in BP. These factors may also address the indirect relation between sodium intake in early life and cardiovascular consequences later in life. For example, a higher sodium intake in early infancy, for example, due to high concentrations of sodium in drinking water, is associated with high intake of sodium during adolescence and early adulthood as well. Therefore, we cannot discriminate between the impact of increased sodium intake early in life compared 
with higher sodium intake later in life on BP in adolescence and adulthood.

A limitation of this study includes the diversity of the articles. Of the 25 included studies, $44 \%$ were review studies and as expected most of the randomized controlled trials were performed in animals. There were only a few randomized controlled trial studies that met our inclusion criteria. Given the relevance and importance of this relation, we decided for our scoping review to include both original and review articles of human as well as animal studies. It should be taken into consideration that animal studies and their results may not in all aspects reflect the human situation. Another limitation is that other factors, for example, protein intake in early life may impact later cardiovascular outcome. Higher protein intake early in life is associated with higher growth and increased for overweight and obesity [41], which in turn increases risk of cardiovascular problems later in life [42]. In future studies, differences other than only sodium intake should be taken into account when evaluating the effect of sodium intake on later cardiovascular outcome.

Because we performed a complete search with both search strings and hand search methods in different databases, we were able to identify all of the relevant articles and make a clear overview of the existing literature on this topic.

\section{Conclusion}

Our scoping review provides evidence that higher intake of sodium in the first 6 months after birth may have adverse cardiovascular health outcomes later in life. A clear gap in the literature is the lack of sufficient evidence of cut-off levels of sodium intake in infancy. As only limited studies are performed on this relation, it is recom- mended to conduct more well-designed studies with sufficient follow-up to determine more precisely the effect of sodium intake in infancy on cardiovascular outcome in adulthood and define cut-off levels of sodium intake in infancy.

To avoid excessive sodium intake in the first 6 months of life, the total salt intake from food and drink products should be limited and the addition of salt during preparation should be avoided $[8,43,44]$.

The findings of this scoping review, including the recommendations for further research, are important for health organizations. As cardiovascular disease, including high $\mathrm{BP}$, is one of the major causes of death, prevention through adequate, but not excessive, intake of sodium in the first 6 months of life is crucial for later health.

\section{Disclosure Statement}

The authors declare that they have no competing interests. In addition, Emmerik has written this manuscript independently of her work for the ministry of Health, Welfare and Sport.

\section{Funding Sources}

There are no funding sources to declare.

\section{Author Contributions}

N.E.E. and F.J. participated in designing the study, reviewed all abstracts and articles, interpreted study results, coordinated and drafted the manuscript, revised and approved final manuscript. R.M.E. participated in designing the study, took part as the third reviewer, reviewed and approved final manuscript. All authors read and approved the final manuscript.

\section{References}

1 Gluckman PD, Hanson MA, Mitchell MD. Developmental origins of health and disease: reducing the burden of chronic disease in the next generation. Genome Med. 2010 Feb;2(2):14.

2 de Boo HA, Harding JE. The developmental origins of adult disease (Barker) hypothesis. Aust N Z J Obstet Gynaecol. 2006 Feb;46(1): 4-14.

3 Barker DJ, Robinson RJ. Fetal and infant origins of adult disease. British Medical Journal London; 1992.

4 Campbell N, Correa-Rotter R, Neal B, Cappuccio FP. New evidence relating to the health impact of reducing salt intake. Nutr Metab Cardiovasc Dis. 2011 Sep;21(9):617-9.
5 Strazzullo P, D’Elia L, Kandala NB, Cappuccio FP. Salt intake, stroke, and cardiovascular disease: meta-analysis of prospective studies. BMJ. 2009 Nov;339:b4567.

6 SACN. Salt and health 2003. Available from: https://www.gov.uk/government/uploads/ sys tem/uploads/attachment_data / file/338782/SACN_Salt_and_Health_report. pdf.

7 Menárd. A conceptual framework for the relationship between sodium intake and mortality. Reducing salt intake in populations: report of a WHO forum and technical meeting. World Health Organization; 2007. p. 10.
8 Girardet JP, Rieu D, Bocquet A, Bresson JL, Briend A, Chouraqui JP, et al. [Salt intake in children]. Arch Pediatr. 2014 May;21(5):5218.

9 Miconi G, Molinari D, Festuccia G. Valutazione dell'apporto giornaliero di sodio alimentare nel bambino dei primi due anni di vita. Ann Fac Med Chir Univ Studi Perugia. 1980; 71(4):563-8.

10 Turck D. Alimentation de l'enfant et facteurs de risque cardiovasculaire. Bull Acad Natl Med. 2011 Mar;195(3):487-98.

11 Weidman WH. Hypertension and nutrition in the young: early intervention? Can J Physiol Pharmacol. 1986 Jun;64(6):849-51. 
12 Curtis KS, Krause EG, Wong DL, Contreras RJ. Gestational and early postnatal dietary $\mathrm{NaCl}$ levels affect $\mathrm{NaCl}$ intake, but not stimulated water intake, by adult rats. Am J Physiol Regul Integr Comp Physiol. 2004 Jun;286(6): R1043-50.

13 Contreras RJ, Wong DL, Henderson R, Curtis KS, Smith JC. High dietary $\mathrm{NaCl}$ early in development enhances mean arterial pressure of adult rats. Physiol Behav. 2000 Oct;71(1-2): 173-81.

14 Geleijnse JM, Grobbee DE. High salt intake early in life: does it increase the risk of hypertension? J Hypertens. 2002 Nov;20(11):21214.

15 Geleijnse JM, Hofman A, Witteman JC, Hazebroek AA, Valkenburg HA, Grobbee DE. Long-term effects of neonatal sodium restriction on blood pressure. Hypertension. 1997 Apr;29(4):913-7.

16 Whitten CF, Stewart RA. The effect of dietary sodium in infancy on blood pressure and related factors. Studies of infants fed salted and unsalted diets for five months at eight months and eight years of age. Acta Paediatr Scand Suppl. 1980;279:1-17.

17 Schwartz C, Issanchou S, Nicklaus S. Developmental changes in the acceptance of the five basic tastes in the first year of life. Br J Nutr. 2009 Nov; 102(9): 1375-85.

18 Hanevold CD. Sodium intake and blood pressure in children. Curr Hypertens Rep. 2013 Oct;15(5):417-25.

19 Stein LJ, Cowart BJ, Beauchamp GK. The development of salty taste acceptance is related to dietary experience in human infants: a prospective study. Am J Clin Nutr. 2012 Jan; 95(1):123-9.

20 Strazzullo P, Campanozzi A, Avallone S. Does salt intake in the first two years of life affect the development of cardiovascular disorders in adulthood? Nutr Metab Cardiovasc Dis. 2012 Oct;22(10):787-92.

21 Liem DG. Infants' and children's salt taste perception and liking: a review. Nutrients. 2017 Sep;9(9):1011.

22 Beauchamp GK, Mennella JA. Flavor perception in human infants: development and functional significance. Digestion. 2011;83 Suppl 1:1-6.

23 Mennella JA. Ontogeny of taste preferences: basic biology and implications for health. Am J Clin Nutr. 2014 Mar;99(3):704S-11S.

24 Lava SA, Bianchetti MG, Simonetti GD. Salt intake in children and its consequences on blood pressure. Pediatr Nephrol. 2015 Sep; 30(9):1389-96.

25 Hofman A, Hazebroek A, Valkenburg HA. A randomized trial of sodium intake and blood pressure in newborn infants. JAMA. 1983 Jul; 250(3):370-3.

26 Lawlor DA, Smith GD. Early life determinants of adult blood pressure. Curr Opin Nephrol Hypertens. 2005 May;14(3):259-64.

$27 \mathrm{Wu}$ TC, Chen PH. Health consequences of nutrition in childhood and early infancy. Pediatr Neonatol. 2009 Aug;50(4):135-42.

28 Pomeranz A, Dolfin T, Korzets Z, Eliakim A, Wolach B. Increased sodium concentrations in drinking water increase blood pressure in neonates. J Hypertens. 2002 Feb;20(2):2037.

29 Brion MJ, Ness AR, Davey Smith G, Emmett P, Rogers I, Whincup P, et al. Sodium intake in infancy and blood pressure at 7 years: findings from the Avon Longitudinal Study of Parents and Children. Eur J Clin Nutr. 2008 Oct; 62(10):1162-9.

30 Zinner SH, McGarvey ST, Lipsitt LP, Rosner B. Neonatal blood pressure and salt taste responsiveness. Hypertension. 2002 Sep;40(3): 280-5.

31 Lucas A, Morley R, Hudson GJ, Bamford MF, Boon A, Crowle P, et al. Early sodium intake and later blood pressure in preterm infants. Arch Dis Child. 1988 Jun;63(6):6567.

32 el-Dahr S, Yosipiv IV, Muchant DG, Chevalier RL. Salt intake modulates the developmental expression of renal kallikrein and bradykinin B2 receptors. Am J Physiol. 1996 Mar; 270(3 Pt 2):F425-31.

33 Moreira MC, da Silva EF, Silveira LL, de Paiva $\mathrm{YB}$, de Castro $\mathrm{CH}$, Freiria-Oliveira $\mathrm{AH}$, et al. High sodium intake during postnatal phases induces an increase in arterial blood pressure in adult rats. Br J Nutr. 2014 Dec;112(12): 1923-32.

34 Smriga M, Kameishi M, Torii K. Brief exposure to $\mathrm{NaCl}$ during early postnatal development enhances adult intake of sweet and salty compounds. Neuroreport. 2002 Dec;13(18): 2565-9.

35 Tekol Y. Maternal and infantile dietary salt exposure may cause hypertension later in life. Birth Defects Res B Dev Reprod Toxicol. 2008 Apr;83(2):77-9.

36 Holliday MA. Is blood pressure in later life affected by events in infancy? Pediatr Nephrol. 1995 Oct;9(5):663-6.

37 Pomeranz A, Korzets Z, Vanunu D, Krystal $\mathrm{H}$, Wolach B. Elevated salt and nitrate levels in drinking water cause an increase of blood pressure in schoolchildren. Kidney Blood Press Res. 2000;23(6):400-3

38 Tuthill RW, Calabrese EJ. Drinking water sodium and blood pressure in children: a second look. Am J Public Health. 1981 Jul;71(7):7229.

39 de Jong F, Monuteaux MC, van Elburg RM, Gillman MW, Belfort MB. Systematic review and meta-analysis of preterm birth and later systolic blood pressure. Hypertension. 2012 Feb;59(2):226-34.

40 Singhal A, Cole TJ, Lucas A. Early nutrition in preterm infants and later blood pressure: two cohorts after randomised trials. Lancet. 2001 Feb;357(9254):413-9.

41 Koletzko B, Chourdakis M, Grote V, Hellmuth C, Prell C, Rzehak P, et al. Regulation of early human growth: impact on long-term health. Ann Nutr Metab. 2014;65(2-3):1019.

42 East P, Delker E, Blanco E, Lozoff B, Correa P, Burrows R, et al. BMI Trajectories from Birth to 23 Years by Cardiometabolic Risks in Young Adulthood. Obesity (Silver Spring). 2020;28(4):813-21.

43 Antonios TF. Salt intake in early life and cardiovascular risk. Acta Paediatr. 2000 Apr; 89(4):397-8.

44 Mosser F. Le sel: vigilance dans la première année de vie. Cah Nutr Diét. 2005;40(4):2026.
Dietary Sodium Intake during Infancy and Later Cardiovascular Consequences 